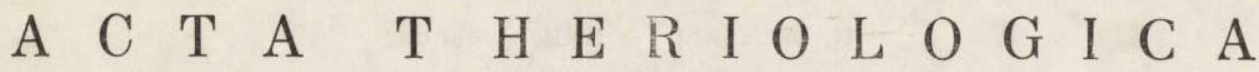 VOL. 18, 9: $191-200$

\section{Food Intake and Digestion by Blacktailed Prairie Dogs under Laboratory Conditions}

\author{
[With 4 Tables]
}

\begin{abstract}
Four consecutive laboratory feeding trials were made on subadult prairie dogs, Cynomys ludovicianus Ord, 1817. Food intake averaged $4.1 \pm 0.14$ grams and live weight gain $0.88 \pm 0.09$ grams per 100 grams of body weight per day in the earliest test and decreased to $2.3 \pm 0.14$ and $0.02 \pm 0.07$ per grams of body weight per day (respectively) in the last test. There was a significant increase in the percent apparent digestion of organic matter (84.5-87.2), gross energy $(84.3-87.0)$, and dry matter (81.6-84.3) from the first to the last feeding period. There was no difference in the apparent digestion of minerals and nutrients by male and female prairie dogs when computed on an equal live weight basis. Males $(\overline{\mathrm{x}}=945 \mathrm{~g}$ ) consumed more energy per day because they averaged $120 \mathrm{~g}$ heavier than females $(\overline{\mathrm{x}}=825 \mathrm{~g})$. The mean live weight of all prairie dogs was $782 \mathrm{~g}$ at start and was $988 \mathrm{~g}$ at the end of the study.
\end{abstract}

\section{INTRODUCTION}

The blacktailed prairie dog, Cynomys ludovicianus Ord, 1817, is a dominant squirrel in much of the area of the Central Great Plains of North America (Costello, 1969). It occurs in the shortgrass and mixed prairie east of the Rocky Mountains from southern Canada to Mexico (Hall \& Kelson, 1959). Blacktailed prairie dogs were estimated to have totaled five billion during the nineteenth century (S e t o n, 1929).

It has been reported that the majority of the plants eaten by prairie dogs are the same plants desired by livestock ( $\mathrm{Kels} \mathrm{o,} \mathrm{1939;} \mathrm{T} \mathrm{a} \mathrm{y} \mathrm{lo} \mathrm{r}$ \& L of tfield, 1924). Smith (1958) reported that blacktailed prairie dog towns are the grazing sites favored by cattle in Kansas. Prairie dogs generally select the most nutritious items to eat, and $\mathrm{K}$ of or d (1958) suggested that competition between prairie dogs and cattle should be judged in terms of calories and nutrients. Laboratory studies involving 
the kcal of food consumed and kcal feces excreted can be used to determine energy intake and apparent digestion of the prairie dogs.

Although much has been written about prairie dogs (Costello, 1970), until now there is little published about the daily consumption and nergetics. It is the objective of this paper to describe the input-output relations of gross energy and some chemical-nutrient components recorded for prairie dogs while consuming a balanced diet in the laboratory, and to estimate the potential energy that prairie dogs may have used in the prairie ecosystem before European man came to North America.

\section{MATERIAL \& METHODS}

The data comprise four feeding trials on a "concentrated ration" which was fed to 20 young blacktailed prairie dogs. This food contained about $16 \%$ natural protein, $2 \%$ fat, and $22 \%$ fiber (Table 1 ). Measurements (at three-day intervals) were taken for food intake, output of feces and body weights of prairie dogs.

Table 1

The mean composition per gram of food (dry weight) for the ration of 20 young blacktailed prairie dogs during four laboratory feeding periods in $\mathbf{1 9 7 0 .}$

Feeding Trial Periods

\begin{tabular}{lccccc}
$\begin{array}{l}\text { Food } \\
\text { Component }\end{array}$ & $\begin{array}{c}\text { Aug. 1 } \\
\text { through } \\
\text { Aug. 21 }\end{array}$ & $\begin{array}{c}\text { Aug. 25 } \\
\text { through } \\
\text { Sept. 8 }\end{array}$ & $\begin{array}{c}\text { Sept. 12 } \\
\text { through } \\
\text { Sept. 27 }\end{array}$ & $\begin{array}{c}\text { Oct. 2 } \\
\text { through } \\
\text { Oct. 31 }\end{array}$ & $\begin{array}{c}\text { Mean } \\
\text { overall } \\
\text { periods }\end{array}$ \\
\hline $\begin{array}{l}\text { Gross energy- } \\
\text { kcal/g }\end{array}$ & 4.4 & 4.3 & 4.4 & 4.4 & 4.4 \\
$\begin{array}{c}\text { Ash \% } \\
\text { Sodium \% }\end{array}$ & 8.7 & 6.9 & 8.4 & 6.9 & 7.7 \\
Potassium \% & 1.6 & 1.6 & 1.7 & 1.7 & 1.7 \\
Phosphorus \% & 1.6 & 1.4 & 1.4 & 1.1 & 1.4 \\
Calcium \% \% & 1.0 & 0.9 & 0.9 & 1.0 & 1.0 \\
Magnesium \% & 0.03 & 0.02 & 0.02 & 0.02 & 0.02 \\
Manganese \% & 0.03 & 0.04 & 0.04 & 0.04 & 0.04 \\
Cobalt \% & 0.3 & 0.01 & 0.03 & 0.03 & 0.03 \\
\hline
\end{tabular}

* The ration was a formulation of natural feeds mixed so it contained about $16 \%$ protein, $2 \%$ fat and $22 \%$ fiber.

Two prairie dogs of the same litter and sex were kept together in each cage throughout the experiments. Excess food and water was always present. The daylight in the laboratory was normal and was not controlled with artificial lights. Ambient laboratory temperature fluctuated around $20^{\circ} \mathrm{C}$.

The dates of the feeding tests in 1970 were: August 1-21; August 25-September 8; September 12-27; and October 2-31. The mean live weight of the prairie dogs was $782 \mathrm{~g}$ at the start and was $988 \mathrm{~g}$ at the end of the study. The average live weight per dog was $857 \mathrm{~g}, 955 \mathrm{~g}, 973 \mathrm{~g}$, and $986 \mathrm{~g}$ for each consecutive feeding 
period, respectively. The young prairie dogs had been kept in their laboratory cages and fed on the concentrated ration for one month before the feeding tests were started.

Forage or feces were each composited for each separate feeding period, on an equal weight basis, for each cage. The pair of "whole samples " for each feeding test were analyzed for oven dry weight, gross energy, ash, potassium, sodium, calcium, cobalt, magnesium, manganese and phosphorous. "Organic matter" was calculated by subtracting the ash weight from the oven dry weight. The mean of a feeding period was derived for each of the ten cages for the chemical-nutrient factors that were determined.

Chemical components were analyzed according to the Association of Official Agricultural Chemists (A.O.A.C.) 1965. Ash was determined by ignition at $600^{\circ} \mathrm{C}$ for $4 \mathrm{~h}$. Mineral elements were measured after samples were wet-ashed. Potassium and sodium were determined with a Beckmann DU-2 spectrophotometer and calcium, magnesium and manganese were estimated with a Perkin-Elmer 290 atomic absorption spectrophotometer. Phosphorus was measured with a B\&L Spectronic 20 colorimeter. Gross energy was determined with a Parr oxygen bomb calorimeter. Oven dry weights were obtained after an air dry sample was kept at $65^{\circ} \mathrm{C}$ for $48 \mathrm{~h}$, cooled in a dessicator to room temperature, and then weighed.

The computed means were tested for statistical significance $(P=0.05)$ by analysis of variance and by co-variance transgenerations. Averages were computed for solid ingesta and solid excreta relationships for each feeding period on an oven dry weight basis.

\section{RESULTS}

The male blacktailed prairie dogs averaged $120 \mathrm{~g}$ heavier in live weight than females ( $945 \mathrm{~g} v s 825 \mathrm{~g}$ ) over all feeding periods. The males consistently ate more food and excreted more feces than did the females. However, on an equal live weight basis the average dry weight of food ingested and the live weight gain was not statistically significantly different between the sexes (Table 2). The apparent digestibility of dry matter, gross energy and minerals was similar for males and females when computed on an equal live weight basis. Therefore, it was possible to standardize the input-output feeding trial data for differences in body weight for all prairie dogs (Table 3).

The feeding tests were started August 1 and lasted until October 31 (three months). Apparently, the young prairie dogs were approaching maturity when the tests were begun because the daily rate of growth was about $1 \%$ of the live weight in the first period, $0.1 \%$ in the second and third periods and only $0.02 \%$ in the last feeding period (Table 2). Also significantly less food and energy was ingested per body weight in each successive feeding period. Forage consumption expressed as a percentage of body weight tends to be highest in the young, and decreases with increasing "physiological age " and weight in all herbivorous mammals. This is due to young herbivores reaching an average forage 
Table 2

The average values $(A V \pm S E)$ computed per $100 \mathrm{~g}$ live body weight per day for the ingestion of food components and live weight gain of 20 young blacktailed prairie dogs during four laboratory feeding trials in 1970.

\begin{tabular}{|c|c|c|c|c|c|}
\hline \multirow[b]{2}{*}{$\begin{array}{l}\text { Component } \\
\text { value } / 100 \mathrm{~g}\end{array}$} & \multicolumn{3}{|c|}{ Feeding Trial Periods } & \multirow[b]{2}{*}{$\begin{array}{l}\text { Oct. } 2 \\
\text { through } \\
\text { Oct. } 31\end{array}$} & \multirow[b]{2}{*}{$\begin{array}{l}\text { Mean } \\
\text { overall } \\
\text { periods }\end{array}$} \\
\hline & $\begin{array}{l}\text { Aug. 1 } \\
\text { through } \\
\text { Aug. 21 }\end{array}$ & $\begin{array}{l}\text { Aug. 25 } \\
\text { through } \\
\text { Sept. } 8\end{array}$ & $\begin{array}{l}\text { Sept. } 12 \\
\text { through } \\
\text { Sept. } 27\end{array}$ & & \\
\hline \multicolumn{6}{|l|}{ Dry weight } \\
\hline Consumption (grams) & $4.1 \pm 0.14$ & $3.8 \pm 0.14$ & $3.0 \pm 0.17$ & $2.3 \pm 0.14$ & $3.3 \pm 0.13$ \\
\hline $\begin{array}{l}\text { Ration gross } \\
\text { energy (kcal) } \\
\text { Organic matter }\end{array}$ & $18.1 \pm 0.63$ & $16.3 \pm 0.59$ & $13.3 \pm 0.76$ & $10.3 \pm 0.64$ & $14.6 \pm 0.58$ \\
\hline $\begin{array}{l}\text { (grams) } \\
\text { Live weight }\end{array}$ & $3.8 \pm 0.13$ & $3.5 \pm 0.13$ & $2.8 \pm 0.16$ & $2.2 \pm 0.13$ & $3.0 \pm 0.12$ \\
\hline gain (grams) & $0.88 \pm 0.09$ & $0.10 \pm 0.03$ & $0.13 \pm 0.05$ & $0.02 \pm 0.07$ & $0.28 \pm 0.07$ \\
\hline
\end{tabular}

Table 3

Average percentage of some food components apparently digested by 20 young blacktailed prairie dogs during four laboratory feeding trials in 1970.*

\begin{tabular}{lccccc}
\hline $\begin{array}{l}\text { Food } \\
\text { Component }\end{array}$ & $\begin{array}{c}\text { Aug. 1 } \\
\text { through } \\
\text { Aug. 21 }\end{array}$ & $\begin{array}{c}\text { Aug. 25 } \\
\text { through } \\
\text { Sept. 8 }\end{array}$ & $\begin{array}{c}\text { Sept. 12 } \\
\text { through } \\
\text { Sept. 27 }\end{array}$ & $\begin{array}{c}\text { Oct. 2 } \\
\text { through } \\
\text { Oct. 31 }\end{array}$ & $\begin{array}{c}\text { Mean } \\
\text { overall } \\
\text { periods }\end{array}$ \\
\hline Organic matter & 84.5 & 85.6 & 86.3 & 87.2 & 85.9 \\
Gross energy & 84.3 & 85.2 & 86.7 & 87.0 & 85.8 \\
Dry matter & 81.6 & 82.8 & 83.6 & 84.3 & 83.1 \\
Ash & 50.9 & 46.1 & 54.3 & 45.0 & 49.1 \\
Sodium & 59.1 & 52.5 & 47.0 & 36.8 & 48.8 \\
Potassium & 53.8 & 42.5 & 34.7 & 20.6 & 37.9 \\
Phosphorus & 24.5 & 19.7 & 18.8 & 16.7 & 20.0 \\
Magnesium & -3.0 & -2.7 & -2.3 & -0.15 & -2.4 \\
\hline
\end{tabular}

* Calculated on a dry weight basis.

consumption rate comparable to that of mature animals sometime before mature weight is reached.

The mean compositions of the four rations fed the prairie dogs was similar for most of the food components (Table 1). Total energy assimilation is likely to be slightly lower than the values we obtained since we did not account for energy losses in the urine. D r o ż d ż (1968) reported that energy losses in urine for wild rodents does not exceed $5 \%$ and for rodents consuming diets of high fiber content the losses are considerably less. The digestion values in this study are a result of the percent of apparent absorbence of the food components on an oven dry weight basis. 
Table 4

Diagonal correlation coefficient matrix for four feeding periods for 20 young blacktailed prairie dogs for the absorbance of various components.

\begin{tabular}{|c|c|c|c|c|c|c|c|c|c|c|c|}
\hline & & Period & WT & GE & ASH & $\kappa$ & $\mathrm{Ca}$ & N. & $\mathrm{Mg}$ & Nin & $\mathrm{P}$ \\
\hline \multirow[t]{4}{*}{ Organic matter } & $=O M$ & 1 & $.999^{*}$ & $.997^{\star}$ & $.900 *$ & $.925 *$ & .101 & $.971 *$ & .076 & $.692 \star$ & .292 \\
\hline & & 2 & .998 * & $.998 *$ & .271 & $.898 *$ & .150 & $.937^{*}$ & -.124 & $.368+$ & .608 * \\
\hline & & 3 & .999 * & $.999 *$ & $.947 *$ & $.971^{*}$ & -.031 & $.991 *$ & -.325 & $.926 \star$ & $.823 *$ \\
\hline & & 4 & $.999^{*}$ & $.999 *$ & $.862 *$ & $.981 *$ & $-.662 \star$ & $.993^{*}$ & $-.848 *$ & $.9577^{\star}$ & .841 * \\
\hline \multirow[t]{4}{*}{ Oven-dry weight } & $=W T$ & 1 & & $.997 *$ & $.912^{\star}$ & $.921 *$ & .096 & $.968 *$ & .085 & $.684 *$ & .279 \\
\hline & & 2 & & $.998 *$ & .327 & $.905 *$ & .175 & $.941 *$ & -.098 & .394 & .596 \\
\hline & & 3 & & $.999 *$ & $.953^{\star}$ & $.975 *$ & -.020 & $.993 *$ & -.317 & $.928 *$ & .828 * \\
\hline & & 4 & $\ldots$ & $.999 *$ & $.869^{*}$ & $.982 \star$ & $-.659 *$ & $.994^{\star}$ & $-.843^{\star}$ & $.956 *$ & .839 * \\
\hline \multirow[t]{4}{*}{ Gross energy } & $=\mathrm{GE}$ & 1 & & & $.903 *$ & $.910^{*}$ & .074 & .968 * & .044 & $.667 *$ & .325 \\
\hline & & 2 & & & .311 & $.895 *$ & .153 & $.939 *$ & -.144 & .363 & $.614 \star$ \\
\hline & & 3 & & & .948 * & $.975 *$ & -.030 & $.993 *$ & -.332 & $.928 *$ & $.829 \star$ \\
\hline & & 4 & & & .856 * & $.978 *$ & $-.678 *$ & .991 * & $-.860 \star$ & $.964 *$ & $.842 \star$ \\
\hline \multirow[t]{4}{*}{ Ash } & $=A S H$ & 1 & & & & $.782 *$ & .008 & $.830^{\star}$ & .198 & .510 & .058 \\
\hline & & 2 & & & & .385 & .454 & .344 & $.780 \star$ & .529 & -.014 \\
\hline & trat & 3 & & & & $.980 *$ & .160 & $.967 *$ & -.171 & $.901 *$ & $.854 *$ \\
\hline & - & 4 & & & & $.883 *$ & -.427 & $.868 *$ & -.572 & $.781 \star$ & $.621 *$ \\
\hline \multirow[t]{4}{*}{ Potassium } & $=k$ & 1 & & & & & .294 & $.961 *$ & -.080 & $.669 *$ & .424 \\
\hline & & 2 & & & & & .460 & $.972 \star$ & -.107 & $.606 *$ & $.693 *$ \\
\hline & . & 3 & & & & & .122 & $.983 *$ & -.313 & $.946 *$ & $.883 \star$ \\
\hline & & 4 & & & & & -.564 & $.995 *$ & $-.807 *$ & $.920 *$ & $.836 *$ \\
\hline \multirow[t]{4}{*}{ Calcium } & $=\mathrm{Ca}$ & 1 & & & & & & $.218^{\circ}$ & .039 & $.504^{\circ}$ & .083 \\
\hline & & 2 & & & & & & .334 & .181 & $.752 *$ & .360 \\
\hline & & 3 & & & & & & .042 & -.120 & .115 & .295 \\
\hline & & 4 & & & & & & -.596 & $.743 *$ & $-.755 *$ & -.529 \\
\hline \multirow[t]{4}{*}{ Sodium } & $=\mathrm{Na}$ & 1 & & & & & & & -.062 & $.748 *$ & .448 \\
\hline & & 2 & & & & & & & -.196 & .451 & $.705 *$ \\
\hline & & 3 & & & & & & & -.347 & $.923 *$ & $.863 *$ \\
\hline & & 4 & & & & & & & $-.832 \star$ & $.938 *$ & $.855 \star$ \\
\hline \multirow[t]{4}{*}{ Magnesium } & $=M g$ & 1 & & & & & & & & .225 & $-.684 *$ \\
\hline & & 2 & & & & & & & & .210 & $-.685 *$ \\
\hline & & 3 & & & & & & & & -.343 & -.417 \\
\hline & & 4 & & & & & & & + & $-.911 \star$ & $-.836 \star$ \\
\hline \multirow[t]{4}{*}{ Manganese } & $=M n$ & 14 & August 1 throug & gh August & 21). & & & & & & .163 \\
\hline & & $2(A$ & August 25 throt & ugh Septem & nber 8 ) & & & & & & .394 \\
\hline & & 3 (s & September $12 \mathrm{t} 1$ & hrough Sep & tember 27 & & & & & & $.652 \star$ \\
\hline & & 4.10 & October 2 throu & ugh Uetobe & er 31) & & & & & & $.822^{\star}$ \\
\hline
\end{tabular}

* Correlation coefficients at the $5 \%$ and $1 \%$ levels of statistical significance at 9 degrees of freedom are .602 and .735 , respectively. 
$\%$ digestion $=100-100 \times \frac{\% \text { component in solid ingesta } \times \text { weight of solid ingesta }}{\% \text { component in solid excreta } \times \text { weight of solid excreta }}$

There was a small but statistically significant $(3 \%)$ increase in the apparent digestibility of organic matter, gross energy and dry matter from the first to the last feeding period (Table 3). There was a signifficant decline of sodium, potassium and phosphorus digested from the first to the last feeding period. Digestion of manganese was less than $1 \%$ but all of the cobalt appeared to have been absorbed. Low and negative digestion indices were recorded for magnesium and calcium in all feeding periods. There was a significant trend from a minus $3 \%$ to a minus $1 \%$ digestion of magnesium from the first to the last feeding period. Calcium values for digestion were between $-0.7 \%$ and $-0.5 \%$ and were not related to the sequence of the feeding periods.

The apparent digestion of organic matter $(Q M)$, oven dry weight $(W T)$, gross energy $(G E)$, potassium $(K)$, and sodium $(N a)$, were positively and significantly correlated $(P=0.01)$ within each feeding period (Table 4). Calcium $(\mathrm{Ca})$ digestion was negatively and significantly correlated with $O M$, WT, $G E$, and manganese $(M n)$ in the fourth feeding period but significantly and positively correlated with $M n$ in the second period. Magnesium $(M g)$ digestion was negatively correlated with $O M, W T, G E$, $K, C a, N a, M n$ in the fourth feeding period and phosphorus $(P)$ in the first, second and fourth feeding periods (Table 4). Phosphorus digestion was significantly positively correlated with $W T$ and $M n$ in the third and fourth feeding periods, and with $O M, G E, K$, and $N a$ in the second, third and fourth feeding periods.

The observed values for the assimilation of minerals and nutrients are within the normal limits reported in the literature for laboratory tests for livestock and other mammals.

\section{DISCUSSION}

Life is dependent upon energy fixed in plants, and we can compare the trade-off value of feeding herbivores on the basis of energy conversion and transfer. Consider the energy of the plants consumed annually by the five billion blacktailed prairie dogs which Seton (1929) and others estimated to have lived in the Central Great Plains of North America before habitation by European man. The removal of energy from the ecosystem by prairie dogs (prior to livestock grazing) can be shown by considering the food energy consumed as a source of energy for the production of meat for human consumption. 
Recently published reports show the diets of cattle include most of the herbaceous species of plants growing in the area historically occupied by prairie dogs (Free et al., 1970; Cook et al., 1967; Merrill et al., 1966; Rice \& Vavra, 1971; Thetford et al., 1971). The published reports on the food plants of prairie dogs ( $\mathrm{K} \mathrm{els} \mathrm{o,} \mathrm{1939;} \mathrm{K}$ of o r d, 1958; C oste 11 o, 1970) suggest that livestock, if grazed at optimum levels of efficiency, would consume mostly the same plants as prairie dogs.

According to $\mathrm{Cook}$ (1971), 24 megacalories of digestible energy are required to produce one $\mathrm{kg}$ of meat in the form of a steer or lamb gaining weight during the spring and summer from native vegetation. Assume that an average prairie dog weighs $750 \mathrm{~g}$ ( $\mathrm{K}$ of or d, 1958; Costello, 1970) and its average digestible energy requirement is $13 \mathrm{kcal}$ per $100 \mathrm{~g}$ of body weight per day $(0.86 \times 15$ wcal $/ 100 \mathrm{~g} /$ day $=$ $=13 \mathrm{kcal} / 100 \mathrm{~g} /$ day). The calories of digestible energy required to feed an average prairie dog per year would be $35,588 \mathrm{kcal}(13 \mathrm{kcal} / 100 \mathrm{~g} / \mathrm{day} \times$ $\times 750 \mathrm{~g} /$ prairie $\operatorname{dog} \times 365$ day $\left./ \mathrm{yr}=3.6 \times 10^{6}\right)$. Therefore, if the digestible energy required by five billion prairie dogs was converted to meat by livestock there would be an annual potential of 741 billion $\mathrm{kg}$ of meat.

$\frac{3.6 \times 10^{6} \mathrm{kcal} / \mathrm{prairie} \operatorname{dog} / \mathrm{yr} \times 5 \text { billion prairie dogs }}{2.4 \times 10^{4}}=741$ billion $\mathrm{kg}$ meat

The per capita consumption of beef per year in the United States at present is about $50 \mathrm{~kg}$. The total beef consumed per year in the United States is about ten billion $\mathrm{kg}(203,000,000$ people in U.S. $\times 50 \mathrm{~kg} /$ person $=$ $=10$ billion). Therefore, if the 17,794 billion megacalories of digestible energy that might have been consumed by five billion prairie dogs were being converted to beef each person now living in the United States could potentially consume about $365 \mathrm{~kg}$ of meat per year. This is equivalent to 7.3 times more beef than that consumed annually in the United States.

The trade-off value of digestible energy consumed by prairie dogs with that of pronghorns and bison, before European man came to the prairies of North America, may nearly approximate the same relations assumed for livestock and prairie dogs. Recent comparisons have been published for the diets and metabolic requirement of livestock, pronghorns and bisons (N a g y \& Hoover, 1971; N a g y et al., 1971; R i c e \& V a vra, 1971; Rice et al., 1971; Peden, 1971; Hyder et al., 1971). There is little doubt that on sites consistently able to annually produce at least $2,000 \mathrm{~kg} / \mathrm{ha}$ prairie vegetation (dry weight) the bison (and now the cattle) was an aid through high grazing intensity to keep the plants short so the prairie dogs could live there and avoid being killed by predators. However, the popular hypothesis that there was a reciprocal ecological 
relation between bison and prairie dogs, each tending to aid the other, seems less and less likely as the scientific community obtains more and better knowledge. If there were a beneficial relationship between bison and prairie dogs it is our hypothesis that it might have been primarily one-sided, the prairie dog taking a population gain whenever it could, but giving almost nothing to the bison in return.

Acknowledgements: I wish to thank Dr. W. Grodziński for critical reading of the manuscript. This research was supported by the Colorado State University Experiment Station.

\section{REFERENCES}

1. Association Official Agricultural Chemists, 1965: A.O.A.C. Benjamin Franklin Station. Washington, D.C. 957 p.

2. Cook, C. W., Harris, L. E. \& Young, M. C., 1967: Botanical and nutritive content of diets of cattle and sheep under single and commun use on mountain range. J. Anim. Sci., 26, 5: 1169-1174.

3. Cook, C. W., 1971: Why not say it the way it is! J. Range Manage., 24, 4: $320-321$.

4. Costello, D. F., 1969: The prairie world. Thomas Y. Crowell Co.: 1-242. New York. (L. C. Card 69-15413).

5. Coste11o, D. F., 1970: The world of the prairie dog. J.B. Lippincott Co.: $1-160$, New York. (L.C. Card 70-110650).

6. Drózd $\dot{z}$, A., 1968: Digestibility and assimilation of natural foods in small rodents. Acta theriol., 13, 21: 367-389.

7. Free, J. C., R. M. Hansen \& P. L. Sim s 1970: Estimating dry weights in foodplants in feces of herbivores. J. Range Manage., 23, 4: 300-302.

8. Ha 11, E. R. \& K. R. Kels o n, 1959: The mammals of North America. The Ronald Press Co.: 546. New York.

9. H y der, D. N., K. L. Kn ox, \& C. L. Stre et er, 1971: Metabolic components of cattle under light and heavy rates of stocking in 1970. U.S. IBP Grassland Biome Technical Report No. 128: 1-40. Natural Resources Ecology Laboratory, Fort Collins, Colo. U.S.A.

10. Kels o, L. H., 1939: Food habits of prairie dogs. U.S.D.A. Circular No. 529: 115. Washington, D.C.

11. K of or d, C. B., 1958: Prairie dogs, whitefaces, and blue grama. Wildlife Monographs, 3: $1-78$.

12. Merrill, L. B., P. O. Reardon \& C. L. Leinwe ber, 1966: Cattle, sheep, goats-mix'em up for higher gains. Texas Agr. Prog., 12: 13-14.

13. N a g y, J. G., K. L. Knox \& D. E. W e s le y, 1971: Metabolic studies of pronghorn antelope. U.S. IBP Grassland Biome Technical Report No. 88: 1--11. Natural Resources Ecology Laboratory, Fort Collins, Colo., U.S.A.

14. N a g y, J. S. \& J. P. H o ove r, 1971: Pronghorn angelope field food consumption studies. U.S. IBP Grassland Biome Technical Report No. 87: 1-63. Natural Resources Ecology Laboratory, Fort Collins, Colo., U.S.A.

15. Peden, D. G., 1971: Preliminary activities and results in bison research on the Pawnee Site. U.S. IBP Grassland Biome Technical Report No. 121: 1-8. Natural Resources Ecology Laboratory, Fort Collins, Colo., U.S.A. 
16. Rice, R. W. \& M. V a vra, 1971: Botanical species of plants eaten and intake of cattle and sheep grazing shortgrass prairie. U.S. IBP Technical Report No. 103: 1-21. Natural Resources Ecology Laboratory, Fort Collins, Colo., U.S.A.

17. R ice, R. W., J. G. Nagy \& D. G. Peden, 1971: Functional interactions of large herbivores on grasslands. Range Science Series No. 10: 241-265,Natural Resources Ecology Laboratory, Fort Collins, Colo., U.S.A.

18. Seton, E. T., 1929: Lives of game animals. Doubleday, Doran \& Co.: 1-746. Garden City, New York.

19. S mith, R. E., 1958: Natural history of the prairie dog in Kansas. Univ. Kansas Mus. Nat. Hist. Miscellaneous Publ., 16: 1-36.

20. T a y 1 or, W. P. \& J. V. G. L of tfield, 1924: Damage to range grasses by the zuni prairie dog. U.S.D.A. Bull. No. 1227: 1-16. Washington, D.C.

21. Thetford, F. O., R. D. Pieper \& A. B. Nelson, 1971: Botanical and chemical compositions of cattle and sheep diets on pinyon-juniper grassland range. J. Range Manage., 24, 6: 425-431.

Accepted, January 31, 1973.

Department of Range Science,

Colorado State University,

Fort Collins, Colorado 80521, U.S.A.

Richard M. HANSEN i Barbara R. CAVENDER

\section{POBRANIE POKARMU I JEGO STRAWNOSC U NIESWISZCZY W WARUNKACH LABORATORYJNYCH}

\section{Streszczenie}

Nieświszcze, Cynomys ludovicianus ( $\mathrm{Ord}$, 1817), występują licznie na preriach amerykańskich na wchód od Gór Skalistych, od południowej Kanady aż po Meksyk. Na pastwiskach mogą one konkurować z bydłem domowym, ponieważ odżywiają się tymi samymi roślinami.

$\mathrm{Na} 20$ dorastających nieświszczach, w ciągu trzech miesięcy wykonano 4 kolejne serie doświadczeń żywieniowych, z których każda trwała 15-18 dni. Zwierzęta trzymano dwójkami w klatkach metabolicznych, karmiono je standardową paszą (Tabela 1), określano dokładnie konsumpcję i fekalia. Pasza i kał były analizowane na suchą masę, wartość kaloryczną, zawartość popiołu i materii organicznej oraz potas, sód, wapń, kobalt, magnez i fosfor.

W ciągu trzech miesięcy doświadczeń nieświszcze przyrosły średnio od $782 \mathrm{~g}$ do 988 g ciężaru ciała, jednak tempo przyrostu wyraźnie malało w miarę jak zwierzęta dojrzewały (Tabela 2). Dobowa konsumpcja pokarmu osiągała średnio $3,3 \mathrm{~g}$ paszy/100 g ciała - doba, co odpowiada $15 \mathrm{kcal} / 100 \mathrm{~g}$ ciała - doba. Konsumpcja liczona na jednostkę ciężaru ciała (100 g) zmniejszała się jednak od $4,1 \pm 0,14 \mathrm{~g}$ w pierwszej serii doświadczeń do $2,3 \pm 0,14 \mathrm{~g}$ w ostatniej serii (18-15 kcal/dobę), co wiązało się ze wzrostem badanych zwierząt (Tabela 2). Nieświszcze posiadają wysoką strawność pokarmów (tj. konsumpcja minus kał). Strawność osiągała średnio 
$85,8 \%$ w stosunku do energii pokarmu, $85,9 \%$ w stosunku do materii organicznej i $83,1 \%$ dla suchej masy (Tabela 3). Stwierdzono istotną poprawę strawności tych składników pokarmu (o 2,7\%) w miarę jak zwierzęta dorastały. Nie było natomiast różnic w konsumpcji i strawności paszy pomiędzy samcami i samicami, jeżeli przeliczać ją na jednostkę ciężaru ciała (samce były średnio cięższe o $120 \mathrm{~g}$ ). Wykonano analizę korelacji strawności składników odżywczych i mineralnych paszy we wszystkich seriach doświadczeń (Tabela 4).

Roczne zapotrzebowanie pokarmowe nieświszcza o średnim ciężarze ciała $(750 \mathrm{~g})$ można ocenić na 35.588 kcal energii strawnej. Szacuje się, iż przed kolonizacją europejską Ameryki Pn. i wprowadzeniem hodowli bydła, na preriach żyło około $5 \mathrm{mi}-$ liardów nieświszczy. Musiały więc pobierać one rocznie paszę zawierającą $17.794 \times$ $\times 10^{12} \mathrm{kcal}$ energii strawnej. Jeżeli by dzisiaj przeznaczyć taką ilość paszy dla wysokowydajnego bydła, to konsumpcja mięsa w USA mogłaby wzrosnąć jeszcze 7,3 krotnie! 